\title{
Sentence structure of thought content and its transmission in Slovak language
}

\author{
[Vetne struktury vyjadrenia myslienkoveho obsahu a jeho prenosu \\ v slovencine]
}

\author{
Peter Gregorik
}

DOI: $10.18355 /$ XL.2019.12.04.04

\begin{abstract}
In the paper we focused on elementary sentence structure ,thought content and its transmission". The research is based on combination of semantic and formal syntactic analysis using method of specific verb description and method of thematic roles. Within the elementary sentence structure we specified four basic language microsituations: obtaining of information, sending of information, owning of information, and mutual sharing of information. Within every microsituation we define its semantic and formal structure with examples. At the end of the paper there is a table with the results.
\end{abstract}

Key words: sentence, structure, syntax, thought content, information

\begin{abstract}
Abstrakt
V príspevku sa zaoberáme elementárnou vetnou štruktúrou „myšlienkový obsah a jeho prenos“. Výskum je založený na kombinácii sémantickej a formálnej syntaktickej analýzy s použitím metódy špecifikovaného opisu slovesa (specific verb description) a metódy tematických rol. V elementárnej vetnej štruktúre špecifikujeme štyri základné jazykové mikrosituácie: získavanie informácie, odosielanie informácie, vlastníctvo informácie a recipročné odovzdávanie informácie. V rámci každej mikrosituácie definujeme jej sémantickú a formálnu štruktúru s príkladmi. Na konci príspevku je tabul'ka s výsledkami.
\end{abstract}

Kl’účové slová: veta, štruktúra, syntax, myšlienkový obsah, informácia

\section{Úvod}

Veta je základnou jednotkou syntaktického systému jazyka, a hoci si intuitívne každý dokáže predstavit', čo to je, jej definícia nie je jednoduchá. Na vetu sa dá nazerat' z rôznych hl'adísk, ked’že sa v nej stretávajú jednotky a javy z viacerých jazykových rovín, počnúc zvukovou rovinou, pokračujúc cez lexikálnu, morfologickú a syntaktickú rovinu, no a končiac špecifickou textovou rovinou. Každá veta má svoje intonačné stvárnenie, jednotky, ktoré ju vytvárajú, využívajú potrebné morfologické kategórie, pre špecifické vetné konštrukcie sú potrebné slová so špecifickým lexikálnym významom. Už v 4. storočí pred n. 1. staroindický gramatik Pánini venoval syntaktickým vzt’ahom čast' svojej gramatiky Asthadyayi, u nás známej ako „Osem kníh“. Hoci v jeho diele nenájdeme definíciu vety, použival výraz vākya, ktorý by sme dnes mohli vol’ne preložit' ako všeobecný pojem pre výpoved'. Prvú známu definíciu vety podal až o storočie neskôr iný sanskritský gramatik Kātyāyana, ktorý vetu definoval ako skupinu slov obsahujúcu verbum finitum. (Coward - Raja, 1990: 83). Veta odvtedy stojí v pozornosti bádatel'ov nielen z oblasti lingvistiky, ale aj iných vedných disciplín. Napriek tomuto dlhému časovému obdobiu stále nemožno jednoznačne definovat', čo je to veta.

\section{Metodologické východiská}

Z pohl'adu tejto štúdie je veta ako základná komunikačno-informačná jednotka realizáciou ustálenej sémanticko-syntaktickej schémy súvzt'ažnej s prvkami istej komunikačnej mikrosituácie. Napr. mikrosituácia, v ktorej niekto oznamuje niečo niekomu, si vyžaduje

\footnotetext{
XLinguae, Volume 12, Issue 4, October 2019, ISSN 1337-8384, eISSN 2453-711X
} 
toho, kto oznamuje (zdroj), toho, kto informáciu prijíma (recipienta), a samotnú informáciu. Jazyk, samozrejme, nemôže zobrazit' skutočnost' bezprostredne a v úplnosti, ale iba výberovo. V jazykovom sprostredkovaní mikrositúcie má ústredné miesto predikátor ( $\mathrm{v}$ najširšom zmysle ho môžeme stotožnit' s prísudkom dvojčlennej vety či vetným zákldom jednočlennej slovesnej vety), ktorý usúvzt’ažňuje jednotlivé prvky participanty - danej mikrosituácie. Vlastnost' predikátora vytvárat' funkčné pozície nazývame v zhode s P. Karlíkom (Grepl - Karlik, 1998: 29) intenčnou schopnost'ou a konfiguráciu participantov, súhrn funkčných pozícií konkrétneho predikátora, jeho intenčným pol’om. Participantom teda nazývame funkčnú pozíciu predikátora. Ako uvádzajú Grepl a Karlík (1983: 13): „Participanty sémantické struktury věty lze charakterizovat jako jisté role, odpovídajíci „účastníkům“ nebo relevantním „okolnostem“ typizovaných reálnych situací. Jde např. o takové role, jako agens, patiens, recipient, iniciátor, posesor, prožívatel, místo, směr a pod.“ V jazykovede však neexistuje jednoznačná zhoda na počte participantov a ich funkciách. Napr. Ch. Fillmore (1969) rozlišuje osem híbkových pádov: agent, „,counter-agent“, object, result, instrument, source a goal. W. L. Chafe (1970) rozlišuje len dva: agens a paciens. A. McIntyre (2007) uvádza devät' tematických rolí (thematic roles): agent, patient, recipient, beneficiary, theme, experiencer, instrument, goal, source a location. E. Tibenská $(1996,1998)$ vyčleňuje aktívne subjektové participanty: procesor, aktor, iniciátor, kauzátor a realizátor, zároveň objektové participanty: paciens, rezultát, adresát, relant, sociatív a inherent. P. Karlík (Grepl - Karlik, 1998) rozdel'uje sémantické aktanty na: 1. substančné, tie d'alej na fyzikálne objekty (agens, kauzátor, procesor, nositel', posesor, expirient, recipient, beneficient, patiens, stimul, instrument, vehikel) a aktanty miesta (locus, direktiv, origativ) a 2. situačné (informácia, inštrukcia, podnet, účel). (Grepl - Karlik, 1998: 38 41). J. Nižníková (2001) vymedzuje až 64 sémantických participantov. Z uvedeného krátkeho prehl'adu vidiet', že jednotliví autori si zvolili pri vymedzovaní sémantických participantov rôzne metódy a prístupy. My vychádzame z potrieb a požiadaviek konkrétnych jazykových mikrosituácií, pre ktoré predpokladáme isté typizované syntakticko-sémantické participanty. Dôležitá je podl'a nás práve syntakticko-sémantická funkcia, teda to, akú sémantickú rolu plnia v rámci elementárnych vetných štruktúr. Za základné metodologické východisko považujeme kombináciu metódy deskriptívnej špecifikáce slovesa (verb specific description) a metódu sémantických (tematických) rol. Prvou z nich sme vymedzili základnú situačnú schému v rámci konkrétnej jazykovej mikrosituácie. Napríklad, zjednodušene napísané, vyabstrahovaním všeobecných mimojazykových významov pri vetách so slovesami hovorenia dostaneme štruktúry ako niekto povedal niečo, niekto sa rozprával s niekým, d’alšou abstrakciou vymedzíme sémantické roly danej štruktúry ako zdroj, téma, informácia či sociatív.

Najpevnejšie miesto malo $\mathrm{v}$ doterajších prácach o povahe vety chápanie vetného typu ako formálnej štruktúry, resp. ako formalizovaného zápisu takejto štruktúry. Napríklad bežný typ vety s podmetom $\mathrm{v}$ nominatíve, určitým slovesným tvarom a predmetom v akuzatíve má formalizovanú podobu: $\mathbf{S}_{\mathbf{N}}-\mathbf{V F}-\mathbf{S}_{\mathbf{A}}$. Do tohto typu patria vety ako Otec číta noviny. Peter spozoroval včely. Žofia zbožňuje palacinky. Voda obsahuje kyslik. a pod. V uvedených vetách sa realizuje tá istá gramatická štruktúra, no ich sémantickosyntaktická štruktúra je zjavne odlišná. Zjednodušene povedané - ide o činnost', zmyslový stav či vlastnost'. Jednostranné zdôrazňovanie formálneho zloženia vety preto podl’a nás nepostačuje na jej typovú charakteristiku a domnievame sa, že pri skúmaní a opise jazyka treba prihliadat' nielen na systémovú povahu jazykových jednotiek a vzt'ahov medzi nimi, ale tiež na situačné a kontextové faktory. My sme si za základ typológie zvolili sémanticko-rolový model. Východiskom pre tento model sú isté jazykové mikrosituácie vyčlenené z jazykovej reality na základe súboru relevantných jazykovo-sémantických vlastností. Tieto vlastnosti nevyčleňujeme na základe gramatických, ale situačnosémantických kritérií, ktoré sú založené na tom, že špecifický typ jazykovej mikrosituácie si vyžaduje aj špecifické jazykové stvárnenie, resp. špecifickú konfiguráciu sémantických prvkov - participantov, ktoré sa vyjadrujú ustálenou jazykovou formou. Vychádzame 
z koncepcie, že komunikácia prebieha vo viac-menej typizovaných situáciách, pre ktoré sú príznačné isté sémantické participanty. Jazykovú mikrosituáciu chápeme ako výsek z mimojazykovej situácie. Je samozrejmé, že vzhl'adom na mimojazykovú a jazykovú realitu musí byt tento výsek istým spôsobom výberový, nejde o fotografický opis určitej situácie so všetkými jej účastníkmi, súvislost’ami a vzt’ahmi. Jazyk si pri uplatňovaní vnútornej, systémovej paradigmy vyberá v parolovej, vonkajšej podobe tie realizácie, ktoré budú komplexné a pritom komunikačne čo najúčinnejšie. Preto predpokladáme, že aj v oblasti komunikačných mikrosituácii možno vyabstrahovat' isté prvky, ktoré naplnia koncept systémovej komplexnosti. V rámci jednotlivých elementárnych vetných štruktúr (napríklad vyjadrenie existencie, stavu, vlastnosti, polohy a pohybu, odovzdávania a vlastnenia informácie, vlastnenia, činností a procesov) vymedzujeme základné jazykové mikrosituácie založené na špecifickej konfigurácii sémantických participantov. Táto konfigurácia vytvára sémantický vzorec danej mikrosituácie a na jeho základe konkrétny vetný typ. Pre každý sémantický vetný typ vymedzujeme aj jeho formálnu gramatickú štruktúru, príp. ak sa jeden sémantický typ realizuje viacerými gramatickými formami, tak rôzne konfigurácie gramatických prvkov.

\section{Elementárna vetná štruktúra: vyjadrenie myšlienkového obsahu}

Predmetom našej štúdie je elementárna vetná štruktúra vyjadrovanie myšlienkového obsahu a jeho prenos. V jej rámci vymedzíme niekol'ko mikrosituácii s predikátormi, ktoré majú špecifický kategoriálny význam:

a) získanie / získavanie informácie

b) odovzdanie / odovzdávanie informácie/tajenie informácie

c) „vlastnenie“ informácie

d) recipročné odovzdávanie informácie

V rámci týchto skupín možno d'alej vyčlenit' špecifické podskupiny. Predikátory v rámci tejto elementárnej štruktúry otvárajú sémantické pozície zdroj, informácia, adresát, téma, sociatív, a kombinujú sa v rámci intenčného pol’a predikátora podl’a špecifikácie, ktorá je vyžadovaná danou mikrosituáciou.

Charakteristika jednotlivých participantov

a) Zdroj je participant, ktorým sa vyjadruje pôvodca, zdroj informácie či „vlastník“ informácie. J. Nižníková (2001) rozlišuje participant komunikant (pri slovesách hovorenia) a kognizant (pri slovesách kognitívnej činnosti). Ked’že v jednom i v druhom prípade ide o „vlastníka“ nadobudnutej informácie, budeme používat’ univerzálny termín zdroj (podobne ako Ch. Fillmore, 1969 či J. McIntyre, 2007), ktorý sa dá chápat ako „sklad““ aj ako „zásobáreň“. Formálne môže byt' vyjadrený viacerými spôsobmi:

- nominatívom: Viktor Mat'ovčík povedal, že návratnost' investícií sa predpokladá do dvadsiatich rokov.

- kvantitatívnym genitívom: Asi 40 percent l'udí povedalo, že v komunizme im bolo lepšie.

- genitívom v spojení s predložkou od: Dozvedeli sme sa od maliara, že v poslednom čase sa mu nahromadilo vel'a výtvarných aktivit.

- iným predložkovým pádom zastupujúcim nominatív: V televizii hlásili, že na štyroch miestach $v$ Abcházsku sa dnes odohrali ozbrojené zrážky. Na recepcii nám povedali, že o tomto probléme vedia, ale riešit'sa nedá. (internet)

b) Informácia je participant pomenúvajúci to, čo je samotným obsahom informácie. Formálne môže byt' vyjadrený:

- vedl'ajšou vetou, ktorá je najbežnejšou formou pre tento participant: Zatelefonoval mi, že sa stretneme o piatej. (Mitana) Povedali nám, aby sme zmizli z Nemecka. Dozvedeli sme sa tak, kol'ko stoji nielen ochrana osobnosti premiéra, podpredsedov vlády, ministrov, ale aj predsedu senátu Najvyššieho súdu SR. Porozprával Júlii, ako mu matka zmizla. Spýtal sa, či chcem naozaj databázu konvertovat', a viac ani nepípol.

XLinguae, Volume 12, Issue 4, October 2019, ISSN 1337-8384, eISSN 2453-711X 
- akuzatívom: Prorokovala mi z toho tá drahá duša vel'ké št'astie. (Vámoš) Predseda krajskej organizácie trasl'avým hlasom oznámil údajnú existenciu plánu na odstúpenie časti Slovenska Budapešti. Ktosi mi rozprával príbeh o rybárovi.

- genitívom: Tak už som toho natáral dost'. Narozprával už vel'a hlúpostí, ale väčšinou mal aspoň čiastočne pravdu.

- neurčitkom: Prikázali nám nazbierat' na večeru jecchaj - trávu so širokými steblami podobnými listom.

c) Téma je participant, ktorým sa pomenúva, koho či čoho sa informácia týka. Rozdiel medzi informáciou a témou je dost' nezretel'ný. Odlišujeme ich, pretože môžu byt' súčast'ou tej istej vety, ako napr. „Je to s ním čoraz horšie “ " povedal mi o ňom priatel' z jednej finančnej skupiny. Zatial' čo informácia je najčastejšie vyjadrená vedl'ajšou vetou, téma vedl'ajšou vetou vyjadrená nebýva. Jej základnou formou je lokál v spojení s predložkou o: Povedal o ňom, že to možno nie je úplný úspech, je to však vynikajúca štúdia osamelosti a potreby, vyvolávajúca trochu smútku. Režisér o filme povedal, že ilustruje „absurditu každodenného života na Kube“. Môže však byt' vyjadrená i inak, napr. predložkou na + akuzatívom alebo bezpredložkovým akuzatívom: Pýtal sa na Petra, či je spol'ahlivý. Raz vás kolegovia ohovárali, že na zájazdoch ani len neotvorite kufor.

d) Adresát je participant, ktorému je informácia určená, ktorý informáciu prijíma alebo nadobúda. Typickou formou je datív: To som za svoj dlhý život nepovedal Bohu všetko? (Sloboda) Pri predikátoroch nadobúdania informácie má formu nominatívu: Takto sa poslucháč dozvedel, že čilský tenista Rios nie je kooperatívny a že Korda má konštantné údery. Pri istých predikátoroch je vyjadrený akuzatívom: Naučil l'udí, že na jednu pravdu môže existovat' množstvo názorov. O našich postrehoch a záveroch sme informovali aj vedenie Slovenského rozhlasu a Slovenskej televízie. Pri predikátoch s funkciou „tajenia“ informácie sa využíva inštrumentál s predložkou pred: Tieňový kabinet HZDS napriklad tajil pred verejnost'ou svoje zloženie. Rovnako zamlčali pred nami fakt, že vel'koryso riěsená budova patrí už jej.

V expresívnej podobe sa dá využit' aj iná forma, napr. Do mojej spolužiačky si nahustil sladké slová o tom, ako si si uvedomil, že ti chýbam a chceš ma naspät'.

e) Sociatív je objektový participant vyjadrujúci spoluúčastníka deja: Rozprával sa so ženou, ale jej hlas znel bezfarebne a kovovo. Sociatív sa dá v tomto prípade chápat' ako sekundárny komunikant, lebo veta by sa dala prepísat' do formy On a žena sa rozprávali. Myslíme si však, že by to spôsobilo zbytočné komplikácie, a v zhode s E. Tibenskou (1998: 205) používame pre spoluúčastníka deja tento termín.

Uvedené participanty a ich vzájomné kombinácie sa využívajú ako doplnenia špecifických predikátorov. Vzt’ahy medzi predikátormi a participantmi nie sú vol’né, ale sú viazané intenčným pol'om daného predikátora. Napr. predikátor zhovárat' sa otvára tri sémantické pozície - pozíciu pre zdroj (komunikanta), tému a adresáta. Niektoré participanty si predikátor vyžaduje obligatórne, iné iba potenciálne podla potreby a situácie. Napr. predikátor rozprávat' je síce väčšinou doplnený obligatórnymi participantmi (zdroj, informácia), napr. Peter rozprával, ako ho naháňali policajti. Podl’a komunikačnej potreby však možno doplnit' d'alší potenciálny participant a môže vzniknút' veta Peter nám rozprával, ako ho naháňali policajti., zároveň však môže byt' z intenčného pol'a obligatórny participant vynechaný, napr. Peter celý den̆ len rozpráva a rozpráva. $\mathrm{V}$ tejto vete nejde o vyjadrenie odovzdávania obsahu informácie, ale o pomenovanie vykonávaného procesu, ide teda o iný predikátor, konkrétne o predikátor vyjadrujúci proces. 
Patrí sem vel'ká skupina predikátorov, ktoré vyjadrujú, že niekto sa stal/stáva „vlastníkom“ nejakej informácie alebo sa o to usiluje. Základný sémantický vetný typ má štruktúru: adresát - nadobúdanie informácie - informácia

Patria sem napr. predikátory zistit', dozvediet'sa, pochopit', uvedomit' si, naučit'sa, spoznat', príst' (na niečo), napadnút' (niekomu) a pod. Participant informácia je najčastejšie vyjadrený explicitne, vetou. Najbežnejšou gramatickou štruktúrou pre tento sémantický typ je forma: $\mathbf{S}_{\mathbf{N}}-\mathbf{V F}-$ že SENT.

Príklady: Dozvedeli sme sa, že máme ist’ do druhého obchodu na Dunajskej ulici, kde je tiež predajňa spoločnosti NAY. Pochopil som, že to je ešte horšie, než sme si to predstavovali ako deti. Uvedom si, priatel', že tu ide o vysokú politiku. Prišla na to, že rôzne dokumenty, publikované a dokonca aj s príslušnými grafmi, sa mýlia. Bol som tam viac ráz a zistil som, že kopec nenávisti v l’ud'och stále narastá.

Častá je tiež forma s vedl'ajšou vetou uvedenou vzt’ažnými zámenami čo, kto, kde, s kým, ako... Vzorec má formu: $\mathbf{S}_{\mathbf{N}}-\mathbf{V F}$ - pron SENT.

Príklady: S neomylnou opileckou jasnozrivostou si Slávik uvedomil, s kým má tú čest': určite sú to niekol'konásobni recidivisti. (Mitana) Vojak sa naučil, čo je talón, štich, durchmarš. Dozvedel sa, kto vlastne je a čo sa mu stalo.

V záporných vetách sa často vyskytuje štruktúra so spojkou či: $\mathbf{S}_{\mathbf{N}}-\mathbf{V F}$ - či SENT

Príklady: Zatial' sme nevypátrali, či sa už využíva aj na výrobu nejakých sladkých dobrôt, ale rady si na to s vami počkáme. No, že ten somár nezistil, či je tvoj tatko na palube. Victoire spočiatku nepochopila, či to robí zo zvláštneho odporu k týmto miestam, alebo preto, že má taký vzt’ah k veciam. Táto štruktúra sa však často vyskytuje aj vo vetách kladných, ktoré však nevyjadrujú, či informácia platí alebo nie: Pedagóg spoznal, či sa v jeho triede nachádza gembler. Rada by bola uhádla, či sa hnevá, alebo nie.

Použitie špecifického druhu spájacieho výrazu nie je vpredchádzajúcich troch gramatických štruktúrach náhodné, ale každé má špecifickú funkciu a použitie a môžeme ich postavit' do vzájomných opozícií. Ukážeme si to na príklade troch viet:

1) Zistil, že sa koná ples v opere.

2) Zistil, kde sa koná ples.

3) Zistil, či sa koná ples v opere.

$\mathrm{V}$ prvých dvoch vetách je informácia podaná ako pravdivý, hotový fakt, naproti tomu $\mathrm{v}$ tretej vete je informácia nerozhodnutá, nevieme z nej určit', či sa ples koná alebo nekoná, jej pravdivost' je teda otvorená. F. Daneš (1981: 152) hovorí o sémantickej črte asertívnosti, ktorý majú prvé dve vety a tretia ju nemá. Prvá a tretia veta môžu byt' oproti druhej vymedzené vlastnost'ou explicitnej úplnosti. V prvej a tretej vete informácia explicitne obsahuje všetky zložky informácie, napriek tomu, že v tretej vete nevieme nič o jej pravdivosti. V druhej vete zložka informácie miesto nie je vyjadrená, a preto je táto informácia explicitne neúplná. Uvedené vlastnosti môžeme uviest'v tabul'ke.

\begin{tabular}{|l|l|l|}
\hline & ASERTÍVNOSŤ & EXPLICITNÁ ÚPLNOSŤ \\
\hline Zistil, že ... & + & + \\
\hline Zistil, kde ... & + & - \\
\hline Zistil, či ... & - & + \\
\hline
\end{tabular}

Niekedy je možné použit' nominalizáciu informácie, pri ktorej sa vedlajšia veta redukuje na jednoduchý vetný člen: Dozvedel sa, aké boli výsledky. $\rightarrow$ Dozvedel sa výsledky. Martina zistila, že v programe je chyba. $\rightarrow$ Martina zistila chybu v programe. Takéto štruktúry majú formu: $\mathbf{S}_{\mathbf{N}}-\mathbf{V F}-\mathbf{S}_{\mathbf{A}}$ 
Príklady: Práve preto mnohí skrze neho spoznali pravdu, naučili sa, ako ju žit', a tiež to, že láska je jednoduchá a nepotrebuje vznešené slová. Okamžite všetko pochopil a uvedomil si svoju netaktnost'.

Niektoré typy informácie umožňujú $\mathrm{v}$ sémantickej štruktúre potenciálne obsadit' aj participant téma. Sémantický typ má potom schému: adresát - nadobúdanie informácie - informácia - (téma). V gramatickej štruktúre je téma najčastejšie realizovaná lokálom s predložkou $o$. Ak je informácia vyjadrená vedl'ajšou vetou, tak participant téma zvyčajne stojí pred ňou.

Príklady: Môj priatel' sa dozvedel o mne veci, ktoré som mu nikdy nepovedala, lebo som sa hanbila. Pripomenula si, že ona naňho naliehala, aby zašiel za Jane a zistil pravdu o dievčati.

Pre niektoré predikátory v tejto skupine je oproti predchádzajúcim typom typická zmena gramatickej vetnej štruktúry. Sémanticky sú totožné, gramaticky však majú pozmenenú formu. Sémantický participant adresát nie je v pozícii podmetu, ale predmetu a vedl'ajšia veta je v pozícii podmetu: že SENT / či SENT / pron SENT - VF - $\mathbf{S}_{\mathrm{D}}$

Príklady: A došlo mi, že som na rade ja, teraz ma navštívia donovi agenti. Napadlo jej, že zostala prvý raz v dome sama. Za nimi vládlo ticho a svitlo mi, že miestnost' patrí jemu. Fíha, teraz, ked'sa pozerám na tie mená, došlo mi, čo majú skoro všetci spoločné. Ked' som videla, že sa usmieva, napadlo mi, či si zo mňa nerobi posmech.

Do sémantickej štruktúry môže vstúpit' aj participant zdroj. Jeho prítomnost' explicitne vyjadruje, odkial' adresát nadobúda informáciu. Zdrojom môže byt' živá i neživá entita. Sémantická štruktúra má potom štvorčlennú schému: adresát - získavanie informácie informácia - (zdroj). Niektoré predikátory umožňujú prítomnost' tohto participantu (dozvediet' sa, zistit', naučit' sa...), no niektoré nie (spoznat', pochopit', vypátrat'...) Najbežnejšou formou je genitív s predložkou od. Gramatický vzorec má formu:

$\mathbf{S}_{\mathbf{N}}-\mathbf{V F}-$ od $\mathbf{S}_{\mathbf{G}}-$že SENT / či SENT / pron SENT / $\mathbf{S}_{\mathbf{A}}$

Príklady: Povedala mu o svojom vítazstve a vypočula si od neho len šomravé ospravedlnenie. Naučil sa od nich, čo si počat's krevetami, krabmi, chobotnicami, rôznymi mušlami a všakovakými inými darmi mora. Dozvedel sa od neho, že cez prieliv by sa dostal na šire more za devät' dní. Deduško však od nás d'alej vyzvedal, či na Skylinku nepribudli nejaké nové programy. Viac informácii zistoval od hovorcu grécko katolíckeho exarchátu v Košiciach Michala Hospodára redaktor Jaroslav Fabian.

Vety s takouto štruktúrou sú často sémanticky súvzt'ažné s vetami, v ktorých je zdroj vyjadrený nominatívom, podmienkou však je kategória životnosti: Otec sa od syna dozvedel pravdu. / Syn oznámil pravdu otcovi. Pri neživom zdroji informácie to možné nie je: Otec sa z televizie dozvedel pravdu. / Televizia oznámila otcovi pravdu.

Participant zdroj však môže byt' vyjadrený i inak: Z tlačovej správy som sa dozvedela, že v pôvodnej verzii bol Kristián tiě̌ závislý na drogách, ale socialistická cenzúra prinútila autorov zmenit' to na asi menej ideologicky závadný alkohol.

\section{b) Jazyková mikrosituácia „niekto „vlastní‘“ nejakú informáciu“}

Na rozdiel od predchádzajúceho typu sa tento vyznačuje tým, že informácia je prítomná ako mentálne vlastníctvo, ktoré participant nenadobúda, ale sám ním disponuje. Ako predikátory sa v tomto type vyskytujú slovesá myslenia, verba sentiendi. Ide o neakčné slovesá, ktoré vyjadrujú duševnú činnost' človeka. Patria sem napr. predikátory vediet', pamätat' si, pomyslet' si, rozumiet', chápat', predpokladat', verit', tušit', dúfat', pochybovat,' byt' si istý, domnievat' sa a pod. Sémantický vetný typ má štruktúru: zdroj - vlastnenie informácie - informácia. Predikátor väčšinou otvára pozície pre dva participanty (zdroj a informácia), no niektoré predikátory môžu byt' doplnené participantom téma. (Vedel pravdu o rodičoch.) Základná gramatická štruktúra má formu: $\mathbf{S}_{\mathbf{N}}-\mathbf{V F}-\mathbf{z} \mathbf{e} \mathbf{S E N T}$.

Príklady: Ludovit Štúr vedel, že na túto cestu môže vykročit’ iba ten, kto dokáže „,málo trovit', ale vel'a tvorit'“. Zuzana si pamätá, že novinárka použila slovo akt. Neodpovedaj mi, ale aspoň ver, že tvoj hlas bol jediný dosiahnutelný. Nuž, nebol by som si taký istý, že 
SDK je schopné ziskat' viac percent aj v budúcich vol'bách. Domnievame sa, že tento pramen̆ sa vzhl'adom na silné napojenie mohol azda spomenút' aj v úvode encyklopédie.

Štruktúra s explicitne neúplnou informáciou, no s vyjadrenou pravdivostnou hodnotou má formu: $\mathbf{S}_{\mathbf{N}}-\mathbf{V F}$ - pron SENT: Dokáže vysávat' plochu viacerých izieb naraz a pamätá si, kde sa v byte nachádza. Vedel som, ako zúfalo ich budeme potrebovat'. Boli sme si istý, kde napokon skončime.

Explicitne úplná informácia, z ktorej však nevyplýva pravdivostná hodnota, má formu: $\mathbf{S}_{\mathbf{N}}$ - VF - či SENT: Pozrel na tváre l'udi a hned' vedel, či Barca vyhrala posledný zápas. Pamätášs si, či sme vtedy zvítazili?

Pri tomto sémantickom type je dôležité, či predikátor: 1. vyjadruje platnost' výpovede ako istú (vediet', byt' si istý, pamätat' si a pod.) alebo 2. len ako predpokladanú, neistú (predpokladat', pochybovat', verit', dúfat' a pod.). Sémantické vlastnosti prvej skupiny predikátorov umožňujú vytvárat' všetky uvedené gramatické štruktúry: Vedel, že sa zápas uskutočni v Trnave. / Vedel, kde sa uskutoční zápas. / Vedel, či sa zápas uskutoční $v$ Trnave. Sémantické vlastnosti druhej skupiny predikátorov, teda to, že platnost' informácie je iba predpokladaná, umožňujú použitie len v štruktúrach so spojkou že, ktoré ako základné, bezpríznakové umožňujú vyjadrit' akúkol'vek informáciu bez toho, aby platila či neplatila. Možná je veta: Domnieval sa, že sa zápas uskutoční v Trnave. Nie je však možná veta: Domnieval sa, či sa zápas uskutočnív Trnave.

Niektoré predikátory umožňujú doplnit' sémantickú štruktúru o potenciálny participant téma, ktorý sa najčastejšie vyjadruje lokálom a predložkou $o$ : Vedel $o$ ňom, že rád klebetí a je zberatelom cenností. Pochyboval o nej, že to zvládne.

\section{c) Jazyková mikrosituácia „niekto odovzdáva informáciu niekomu“}

Vetné štruktúry tohto typu vyjadrujú, že niekto (zriedkavo i niečo) odovzdáva informáciu niekomu inému. Najväčšiu skupinu predikátorov tvoria slovesá hovorenia (verbá dicendi), no prenos informácie sa môže uskutočňovat' i inou než ústnou formou. Vyčleňujeme štyri skupiny predikátorov podla formy prenosu informácie, a to:

a) zvukovou formou: povedat', rozprávat', telefonovat', rečnit', kričat' a pod.,

b) písanou formou: napisat', mailovat', faxovat', načiarat' a pod.,

c) všeobecné, ktoré môžu byt' použité na zvukovú aj písanú formu: oznámit', požiadat', prikázat', vysvetlit' a pod.,

d) nejazykovou formou: mrknút', gestikulovat' a pod.

Toto členenie však nie je syntakticky relevantné, ked’že predikátory zo všetkých štyroch skupín môžu byt' založené na tej istej syntakticko-sémantickej štruktúre a naopak v rámci tej istej skupiny sa vyskytujú i syntakticko-sémanticky rôzne predikáty (povedat' - rečnit' ...). Predikátor si v mikrosituácii odovzdávania/odovzdania informácie vyžaduje vo svojom intenčnom poli doplnenie o participanty zdroj, informácia a adresát. Adresát však môže byt' v intenčnom poli vynechaný, ak sa chápe ako všeobecný. Zriedkavo môže byt' pri špecifických predikátoroch vynechaná aj informácia (vynadat', zakričat', zavolat' a pod.) Sémantický typ má schému: zdroj - odovzdanie informácie - informácia adresát. Gramaticky sa tento typ realizuje viacerými formami. Najbežnejšou formou je: $\mathbf{S}_{\mathbf{N}}-\mathbf{V F}$ - že SENT - $\left(\mathbf{S}_{\mathbf{D}}\right)$. Patria sem predikátory ako povedat, oznámit', prikázat', rozprávat', hovorit', tvrdit', vysvetlit', objasnit', odkázat', slúbit', ponúknut' a pod.

Príklady: Povedal mi, že nemám všetky svoje pocity ukazovat na plátne, ale mám si niečo nechat' i pre seba. Známy mi rozprával, že sa ráno radšej neholil, ked' sa mal popoludni stretnút's nositel'om HIV. Predavačka mi tvrdila, že dostáva jeden exemplár denne. Janko Melkovič mu ponúkol, že môže prespávat’ u neho. A odkáž mu, že mapa je spolovice hotová.

Adresát môže byt' vynechaný, ak sa chápe ako všeobecný či známy zo situácie: Slúbil, že zavolá, ked' príde do Whangamaty. Povedz, že ti v poslednom čase chýbal. Donedávna som ešte hovoril, že tu máme aspon̆ dva úspešné slovenské podniky: Kabát a Drukos. V niektorých prípadoch je možné namiesto vedl'ajšej vety použit' formu infinitívu

XLinguae, Volume 12, Issue 4, October 2019, ISSN 1337-8384, eISSN 2453-711X 
(zriedkavo i slovesného podstatného mena) alebo vedl'ajšiu vetu nominalizovat': Dovolil mi, aby som cestoval po Európe / cestovat' po Európe / cestovanie po Európe / cestu po Európe.

Participant adresát je často prítomný vo forme datívu vo vetách s gramatickou štruktúrou: $\mathbf{S}_{\mathbf{N}}$ - VF - aby SENT - $\left(\mathbf{S}_{\mathbf{D}}\right)$. Patria sem predikátory ako povedat, prikázat', dovolit', odporučit, navrhnút', poradit' a pod.: Peruánec im povedal, aby ich nechali na pokoji, pretože nič neurobili. Mária Nikolajevna nám navrhla, aby sme vyliezli naň a odtial' sa spúš́ali, s čím sme ochotne súhlasili.

Okrem datívu môže byt' adresát i v inej forme vo vetách s rôznou gramatickou štruktúrou: - v akuzatíve: Nemci ich však informovali, že sú pripravení prijímat' nielen mladých l'udí, ale celé rodiny.

- s predložkou na v akuzatíve: Kričal na mňa, aby som prepustila jeho druhov.

- s predložkou k v dative: Na Staromestskom námestí rečnil k občanom prezident Václav Klaus.

- v genitive: Winston Churchill sa v Jalte neraz pýtal J. V. Stalina, kedy zamýšlajú sovietske vojská obsadit' Gdansk.

- s predložkou pred v inštrumentáli: Chválil sa pred Clintonom, že ten náramok stál tri tisicky.

Podobne ako v predchádzajúcich typoch sa explicitne úplná, no neasertívna výpoved' vyjadruje vedĺajšou vetou so spojkou či: Trochu zvážnel a spýtal sa, či sa vyznám v léziách. Pacientka sa informovala, či už sú výsledky. Explicitne úplná a zároveň asertívna informácia je vo vedl'ajšej vete uvádzaná zámenami kde, kto, čo, ako a pod. Nemecký súd oznámil, kto boli tí, ktorí vraždy organizovali. Oskar by neurobil dobre , keby nám povedal, kde sa nachádza.

Okrem participantu informácia môže byt' v sémantickej štruktúre potenciálne vyjadrený aj participant téma, hoci v niektorých prípadoch je medzi nimi vel'mi nezretel'ná hranica. V niektorých vetách sú oba prítomné a jasne odlíšitel'né: $S$ náramnou dôležitostou mi prišiel zvestovat' o kamarátovi, že spadol do kaluže. Často sa vyskytuje „falošný" participant vyjadrený zámenom: Š. Peciar hovoril o tom, že v spisovnej slovenčine existuje krátenie podl'a rytmického zákona $v$ dvoch smeroch. V tomto prípade nemôžeme hovorit' o samostatnom participante, lebo nemá individuálnu platnost', ale slúži iba ako odkazovací výraz. Aj participant téma, môže mat' okrem základnej podoby aj iné formy, napr. Rečnil proti alkoholu, že je to nebezpečný fenomén. Loboval za kolegu, že je to dobrý odbornik. Spomínal na otca, že to bol dobrý chlap.

Na vyjadrenia neodovzdania, zatajenia informácie sa okrem základného postupu, teda negácie predikátora (Nepovedal jej, že sa mu chlapci posmievajú), používa aj úzka skupina predikátorov, ktoré vyjadrujú negáciu priamo svojím lexikálnym významom (Zatajil, že kmeti dedín sa zväčsa vzpierali, že z chalúp sa ozýval plač. Prečo zamlčala, že ten občan môjho rodného mesta jej vyrážal z rúk nádoby s jedlom?).

\section{d) Jazyková mikrosituácia „recipročné odovzdávanie informácie““}

Vyčleňujeme ju ako osobitný sémantický typ, v ktorom má miesto špecifický participant sociatív. Chápat' by sa však dal i ako osobitná podskupina typu odovzdávanie informácie, hoci $\mathrm{v}$ tomto prípade by sme mali skôr hovorit' o participante téma, ked’že reciprocita predpokladá tematickú súvzt'ažnost' a nie individuálne informácie. Participanty zdroj a sociatív sa dajú chápat' ako rovnocenné a svoje roly si navzájom striedajú. Sémantický vetný typ má podobu: zdroj - recipročná komunikácia - sociatív - (téma / informácia) Bezpríznakovou podobou sociatívu je predložka $s+$ inštrumentál. Väčšinou je spojená s reflexivizáciou predikátora (rozprávat' / rozprávat'sa), niektoré predikátory vyjadrujú reciprocitu priamo svojím lexikálnym významom (debatovat', zhovárat'sa...). Gramatický vzorec má podobu: $\mathbf{S}_{\mathrm{N}}-\mathbf{V F}-\mathbf{s} \mathbf{S}_{\mathbf{I}}-\left(\mathbf{o} \mathbf{S}_{\mathrm{I}}\right)-($ že SENT / pron SENT / či SENT) 
Príklady: Zhováral sa so statným mužom v našich rokoch. Debatoval so mnou aj známy agent Rich Winter, ale ja si pokračovanie svojej hokejovej kariéry viem predstavit' aj doma. Ale radil som sa s manželkou, že túto šancu by som nemal premrhat'.

V nasledujúcej tabul'ke súhrnne podávame charakteristiku jednotlivých mikrosituácií:

\begin{tabular}{|c|c|c|c|}
\hline mikrosituácia & príklad & sémantická štruktúra & gramatická štruktúra \\
\hline $\begin{array}{l}\text { niekto získal/získava } \\
\text { nejakú informáciu }\end{array}$ & $\begin{array}{l}\text { Dozvedel sa, že nikto } \\
\text { nedostane výplatu. }\end{array}$ & $\begin{array}{l}\text { adresát - nadobúdanie } \\
\text { informácie - informácia }\end{array}$ & $\mathrm{S}_{\mathrm{N}}-\mathrm{VF}-\mathrm{SENT} / \mathrm{S}_{\mathrm{A}}$ \\
\hline $\begin{array}{l}\text { niekto „vlastni““ nejakú } \\
\text { informáciu }\end{array}$ & $\begin{array}{l}\text { Peter vie, že mu nikto nič } \\
\text { nedokáže. }\end{array}$ & $\begin{array}{l}\text { zdroj-vlastnenie } \\
\text { informácie - informácia }\end{array}$ & $\mathrm{S}_{\mathrm{N}}-\mathrm{VF}-\mathrm{SENT} / \mathrm{S}_{\mathrm{A}}$ \\
\hline $\begin{array}{l}\text { niekto odovzdáva } \\
\text { informáciu niekomu }\end{array}$ & $\begin{array}{l}\text { Oznámil som veritel'om, } \\
\text { že ma môžu akurát tak } \\
\text { žalovat'. }\end{array}$ & $\begin{array}{l}\text { zdroj-odovzdanie } \\
\text { informácie - informácia - } \\
\text { adresát }\end{array}$ & $\begin{array}{l}\mathrm{S}_{\mathrm{N}}-\mathrm{VF}-\mathrm{SENT}- \\
\left(\mathrm{S}_{\mathrm{D}}\right)\end{array}$ \\
\hline $\begin{array}{l}\text { recipročné } \\
\text { odovzdávanie } \\
\text { informácie }\end{array}$ & $\begin{array}{l}\text { Rozprávali sme sa spolu } \\
\text { s Petrom o problémoch } \\
\text { školy. }\end{array}$ & $\begin{array}{l}\text { zdroj - recipročná } \\
\text { komunikácia - sociatív - } \\
\text { (téma / informácia) }\end{array}$ & $\begin{array}{l}\mathrm{S}_{\mathrm{N}}-\mathrm{VF}-\mathrm{s} \mathrm{S}_{\mathrm{I}}-\left(\text { o } \mathrm{S}_{\mathrm{I}}\right) \\
-(\text { že SENT / pron } \\
\mathrm{SENT} / \text { či SENT) }\end{array}$ \\
\hline
\end{tabular}

Záver: V rámci elementárnej vetnej štruktúry vyjadrenia myšlienkového obsahu sme vymedzili štyri základné jazykové mikrosituácie na základe prítomnosti špecifických predikátorov. Analýzou viet sme vyabstrahovali všeobecné sémantické štruktúry a vymedzili sme možnosti ich formálnych realizácii. Nadviazali sme na domáce výskumy v oblasti intencie slovesného deja i na vlastnú prácu v oblasti elementárnych vetných štruktúr. V štúdii sme použili metódy, ktoré sa pri opise sémantickej stránky vety použivajú aj pri výskume iných jazykov. Praktické využitie vidíme v aplikácii získaných poznatkov v pedagogickej praxi, napríklad pri komunikačnom vyučovaní slovenského jazyka, ktoré je okrem iného zamerané na funkčné využívanie jazykových prostriedkov. Získané poznatky by sa dali využit' aj pri vyučovaní slovenčiny ako cudzieho jazyka, ked’že sémantická valencia je v značnej miere univerzálna, to znamená, že jednotlivé sémantické roly sa dajú vyčlenit' viac-menej vo všetkých jazykoch. Na základe tematickej univerzálnosti by sa tak dali konfrontovat' rozličné gramatické konkretizácie sémantických rol.

Použité skratky: $\mathbf{S}_{\mathrm{N} / \mathrm{G} / \mathrm{D} / \mathrm{A} / \mathrm{L} / \mathbf{I}}-$ substantívum v konkrétnom páde; $\mathbf{S E N T}$ - vedl'ajšia veta; VF - verbum finitum, PRON - zámeno

Poznámka: Príklady v texte, pri ktorých nie je uvedený autor, pochádzajú zo Slovenského národného korpusu.

\section{Bibliographic references}

ALLERTON, D. J. 2008. Verbs and their Satellites In: The Handbook of English Linguistics. Wiley-Blackwell, 2008, pp. 146-179. ISBN: 1405102527.

ALLERTON, D. J. 2016. Essentials of grammatical theory: A consensus view of syntax and morphology. Routledge, ISBN: 131551995X.

COWARD, H. G. - RAJA K. K. 1990. Encyclopedia of Indian philosophies. Volume

5. Motilal: Banarsidas, ISBN 9780691635705.

CHAFE, W. L. 1970. c. Chicago: Chicago Press, ISBN: 978-0226100555.

DANES, F. - HLAVSA, Z. a kol. 1981. Vetné vzorce v cestine. Praha: Academia.

DEKANY, E. 2019. Foundations of generative linguistics. In: Acta Linguistica Academica, vol. 66, n. 3, pp. 309-334. ISSN: 2559-8201.

FILLMORE, CH. 1969. Types of Lexical information. In: Studies in Syntax and Semantics. Dordrecht: F. Kiefer, 1969. pp. 109 - 137. ISBN: 978-90-277-0597-6. 
GREPL, M. - KARLIK, P. 1983. Gramaticke prostredky hierarchizace semanticke struktury vety. Brno: Univerzita J. E. Purkyně.

GREPL, M. - KARLIK, P. 1998. Skladba cestiny. Olomouc: Votobia, ISBN 80-7198281-4.

HEINE, B. - NARROG, H. 2009. The Oxford Handbook of Linguistic Analysis. Oxford: Oxford university Press. ISBN: 9780199544004.

KUIKEN, F. - VEDDER, I. - HOUSEN, A. - DE CLERQ, B. 2019. Variation in syntactic complexity: Introduction. In: International Journal of Applied Linguistics, vol. 29, n. 2, pp. 161-170. ISSN: 1473-4192.

KUMOROVA, Z. 2016. Problems of teaching the official language in the environment of minorities. In: Turkish Online Journal of Educational Technology, vol. 2015, pp. 459-463. ISSN: $1303-6521$.

LEVIN, B. - RAPPAPORT HOVAV, M. 2005. Argument realization. Cambridge: Cambridge University Press. ISBN: 0521663768.

MCINTYRE, A. 2007. Particle Verbs and Argument Structure. In: Language and Linguistics Compass, vol. 4, n. 1. pp. 350 - 367. ISSN: 1749-818X.

NEWMEYER, F. J. 2008. Universals in syntax. In: Linguistic Review, vol. 25(1-2), pp. 35-82. ISSN: 0167-6318.

NIZNIKOVA, J. 2001. Vetne modely v slovencine. Presov: Presovska univerzita. ISBN 80-89038-10-7.

PANINI. 1897. The Ashtadhyayi. 1897.

SKLADANA, J. 2016. Jan Stanislav a jazykova kultura. In: Slavica Slovaca, vol. 51, n. 2, pp. 147-154. ISSN: 0037-6787.

TIBENSKA, E. 1996.Vetne typy s aktivnym subjektom v slovencine. In: Studia Academica Slovaca 25. Bratislava: Stimul - Centrum informatiky a vzdelávania FF UK, 1996, pp. 226 - 238. ISBN: 80-85697-31-9.

TIBENSKA, E. 1998. Objektovy participant semantickej struktury vety. In: Slovenska rec. vol. 63, pp. 198 - 209. ISSN 1337-6853.

TIBENSKA, E. 2017. .Vyjadrovanie fyzickych stavov zivej substancie v slovanskych jazykoch. In: Studia z Filologii Polskiej i Slowianskiej. vol. 52, pp. 210-228. ISSN: 23922435

Words: 5053

Characters: 35407 (19,67 standard pages)

Peter Gregorík

Department of Slovak Language and Literature

Faculty of Arts

University of Sts. Cyril and Methodius in Trnava

Namestie J. Herdu 2

91701, Trnava

Slovakia

peter.gregorik@ucm.sk 